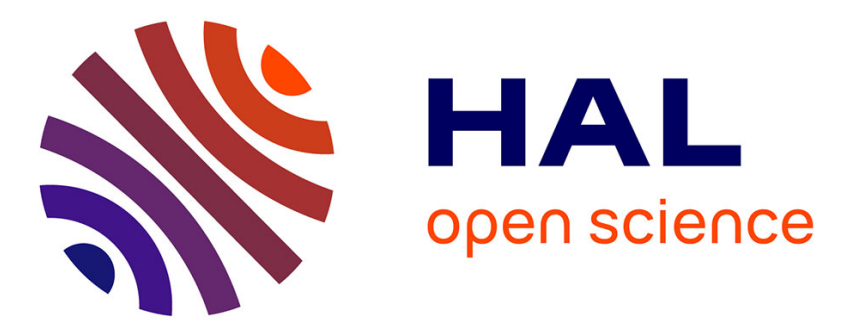

\title{
Spectroscopy and high-power laser operation of a monoclinic $\mathrm{Yb} 3+: \mathrm{MgWO} 4$ crystal
}

Pavel Loiko, Mengting Chen, Josep Maria Serres, Magdalena Aguiló, Francesc

Díaz, Haifeng Lin, Ge Zhang, Lizhen Zhang, Zhoubin Lin, Patrice Camy, et al.

\section{- To cite this version:}

Pavel Loiko, Mengting Chen, Josep Maria Serres, Magdalena Aguiló, Francesc Díaz, et al.. Spectroscopy and high-power laser operation of a monoclinic $\mathrm{Yb} 3+: \mathrm{MgWO} 4$ crystal. Optics Letters, 2020, 45 (7), pp.1770-1773. 10.1364/OL.389627 . hal-03346141

\section{HAL Id: hal-03346141 \\ https://hal.science/hal-03346141}

Submitted on 7 Oct 2021

HAL is a multi-disciplinary open access archive for the deposit and dissemination of scientific research documents, whether they are published or not. The documents may come from teaching and research institutions in France or abroad, or from public or private research centers.
L'archive ouverte pluridisciplinaire HAL, est destinée au dépôt et à la diffusion de documents scientifiques de niveau recherche, publiés ou non, émanant des établissements d'enseignement et de recherche français ou étrangers, des laboratoires publics ou privés. 


\title{
Spectroscopy and high-power laser operation of monoclinic $\mathrm{Yb}^{3+}: \mathrm{MgWO}_{4}$ crystal
}

\author{
Pavel Loiko, ${ }^{1,3}$ Mengting Chen, ${ }^{1,4}$ Josep Maria SerRes, $^{1}$ \\ Magdalena Aguiló, ${ }^{1}$ Francesc Díaz, ${ }^{1}$ Haifeng Lin, ${ }^{2}$ Ge Zhang, ${ }^{2}$ \\ LIZHen Zhang, ${ }^{2}$ ZHOUbIN LIN, 2 PATRICE CAMY, ${ }^{3}$ SHI-Bo DAI, ${ }^{4}$ \\ Zhendiang Chen, ${ }^{4}$ Yongguang Zhao, ${ }^{5}$ LI Wang, ${ }^{5}$ Weidong Chen, ${ }^{2,5},{ }^{*}$ \\ UWe Griebner, ${ }^{5}$ Valentin Petrov, ${ }^{5}$ and Xavier Mateos, ${ }^{1}$
}

\author{
${ }^{1}$ Física i Cristal·lografia de Materials i Nanomaterials (FiCMA-FiCNA)-EMaS, Dept. Química Física i Inòrganica, Universitat Rovira i Virgili (URV), \\ Campus Sescelades, E-43007 Tarragona, Spain \\ ${ }^{2}$ Key Laboratory of Optoelectronic Materials Chemistry and Physics, Fujian Institute of Research on the Structure of Matter, Chinese Academy \\ of Sciences, Fuzhou, 350002 Fujian, China \\ ${ }^{3}$ Centre de recherche sur les lons, les Matériaux et la Photonique (CIMAP), UMR 6252 CEA-CNRS-ENSICAEN, Université de Caen, 6 Boulevard du \\ Maréchal Juin, 14050 Caen Cedex 4, France \\ ${ }^{4}$ Department of Optoelectronic Engineering, Jinan University, Guangzhou 510632, China \\ ${ }^{5}$ Max Born Institute for Nonlinear Optics and Short Pulse Spectroscopy, Max-Born-Str. 2a, D-12489 Berlin, Germany \\ *Corresponding author: chenweidong@fjirsm.ac.cn
}

Received XX Month XXXX; revised XX Month, XXXX; accepted XX Month XXXX; posted XX Month XXXX (Doc. ID XXXXX); published XX Month XXXX

\begin{abstract}
Monoclinic (wolframite-type) monotungstate crystals are promising for rare-earth-doping. We report polarized room- and low-temperature spectroscopy, and efficient high-power laser operation of such a $\mathrm{Yb}^{3+}: \mathrm{MgWO}_{4}$ crystal featuring high stimulated-emission cross-section $\left(\sigma_{\mathrm{SE}}=6.2 \times 10^{-20} \mathrm{~cm}^{2}\right.$ at $1056.7 \mathrm{~nm}$ for light polarization $\left.E \| N_{\mathrm{m}}\right)$, large Stark splitting of the ground-state $\left(765 \mathrm{~cm}^{-}\right.$ 1), large gain bandwidth (26.1 $\mathrm{nm}$ for $\left.E \| N_{\mathrm{g}}\right)$ and strong Raman response (most intense mode at $916 \mathrm{~cm}^{-1}$ ). A diode-pumped $\mathrm{Yb}^{3+}: \mathrm{MgWO}_{4}$ laser generated $18.2 \mathrm{~W}$ at $\sim 1056 \mathrm{~nm}$ with a slope efficiency of $\sim 89 \%$ and a linearly polarized laser output. (C) 2019 Optical Society of America
\end{abstract}

http://dx.doi.org/10.1364/OL.99.099999

Recently, monoclinic wolframite-type ((Fe,Mn) $\mathrm{WO}_{4}$, sp. gr. $\left.P 2 / c\right)$ magnesium tungstate crystals, $\mathrm{MgWO}_{4}$, have emerged as promising host materials for doping with rare-earth ions $\left(\mathrm{RE}^{3+}\right)$ [1-3]. They belong to the crystal family of monoclinic transition metal monotungstates $\mathrm{M}^{2+} \mathrm{WO}_{4}$ (where $\mathrm{M}=\mathrm{Mg}, \mathrm{Zn}, \mathrm{Mn}, \mathrm{Fe}, \mathrm{Ni}$, etc.) [4]. So far, $\mathrm{MgWO}_{4}\left(a=4.6889 \AA, b=5.6753 \AA, c=4.9289 \AA, \beta=90.726^{\circ}[5]\right)$ crystals were mostly studied for scintillators and for doping with transition-metal ions, e.g., $\mathrm{Cr}^{3+}[5,6]$. $\mathrm{MgWO}_{4}$ exhibits good thermomechanical properties (high thermal conductivity $\langle K\rangle$ of $8.7 \mathrm{~W} /(\mathrm{mK})$ [7] and low anisotropy of thermal expansion: $\alpha_{\mathrm{a}}=11.22, \alpha_{\mathrm{b}}=8.09$ and $\left.\alpha_{\mathrm{c}}=8.77\left[10^{-6} \mathrm{~K}^{-1}\right][3]\right)$. These properties are superior compared to another well-known crystal family of monoclinic double tungstates, $\mathrm{KLn}\left(\mathrm{WO}_{4}\right)_{2}$ [8], for which $<\mathrm{k}>\approx 3.5 \mathrm{~W} / \mathrm{mK}$ and the thermal expansion tensor shows a significant anisotropy [9]. Besides, $\mathrm{RE}^{3+}$-doped $\mathrm{MgWO}_{4}$ shows attractive spectroscopic properties (broad and intense emission bands for polarized light, large Stark splitting, high luminescence quantum yield and Raman activity) [1-3]. These advantages originate from the low-symmetry structure and the substantial difference in ionic radii of the $\mathrm{RE}^{3+}$ dopants and the host-forming $\mathrm{Mg}^{2+}$ cations [10].

Regarding laser operation of $\mathrm{RE}^{3+}$-doped $\mathrm{MgWO}_{4}$ crystals, previous studies focused mostly on the spectral range of $\sim 2 \mu \mathrm{m}$ using thulium $\left(\mathrm{Tm}^{3+}\right)[2,10-12]$ and holmium $\left(\mathrm{Ho}^{3+}\right)[3]$ ion doping. A diode-pumped continuous-wave (CW) $\mathrm{Tm}^{3+}: \mathrm{MgWO}_{4}$ laser generated $3.09 \mathrm{~W}$ at $2022-2034 \mathrm{~nm}$ with a slope efficiency $\eta$ of $50 \%$ [11]. A graphene mode-locked (ML) $\mathrm{Tm}^{3+}: \mathrm{MgWO}_{4}$ laser delivered $86 \mathrm{fs}$ pulses at $2017 \mathrm{~nm}$ featuring a bandwidth of $53 \mathrm{~nm}$ at a repetition rate of $76 \mathrm{MHz}$ [12].

For laser emission at $\sim 1 \mu \mathrm{m}$, ytterbium $\left(\mathrm{Yb}^{3+}\right)$ ion doping holds a huge potential. This is because $\mathrm{Yb}^{3+}$ has a simple energy-level scheme eliminating the unwanted energy-transfer processes and leading to high Stokes pump efficiency and weak heat loading [13]. The larger Stark splitting of the ground-state $\left({ }^{2} \mathrm{~F}_{7 / 2}\right)$ (as compared to $\mathrm{Nd}^{3+}$ ) is a prerequisite for broader emission at $\sim 1 \mu \mathrm{m}$. So far, the growth and preliminary spectroscopy of $\mathrm{Yb}^{3+}: \mathrm{MgWO}_{4}$ crystal were reported $[1,14]$. A semiconductor saturable absorber mirror 


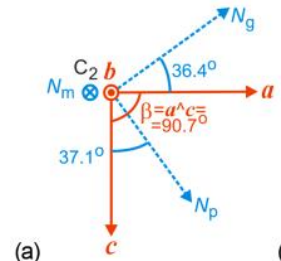

(a)

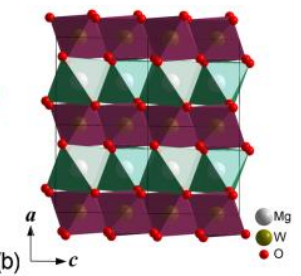

Fig. 1. (a) Orientation of the optical indicatrix axes $\left(N_{\mathrm{p}}, N_{\mathrm{m}}\right.$ and $\left.N_{\mathrm{g}}\right)$ in monoclinic Yb:MgWO 4 crystal: $\boldsymbol{a}, \boldsymbol{b}$ and $\boldsymbol{c}$ - crystallographic axes, $\mathrm{C}_{2}-2$ fold symmetry axis; (b) crystal structure in projection to the $\boldsymbol{a}$ - $\boldsymbol{c}$ plane.

(SESAM) ML Yb ${ }^{3+}: \mathrm{MgWO}_{4}$ laser delivered 125 fs pulses at 1065 $\mathrm{nm}$ at a repetition rate of $117 \mathrm{MHz}$ [15].

In this work, we report a detailed room- and low-temperature polarization-resolved spectroscopy of $\mathrm{Yb}^{3+}: \mathrm{MgWO}_{4}$ paving the way towards its highly-efficient and high-power diode-pumped laser operation. We consider this work as a first step towards high-power mode-locked bulk and thin-disk lasers based on $\mathrm{Yb}^{3+}: \mathrm{MgWO}_{4}$.

The 1.25 at.\% $\mathrm{Yb}^{3+}: \mathrm{MgWO}_{4}$ crystal was grown by the Top-Seeded Solution Growth (TSSG) method using $\mathrm{Na}_{2} \mathrm{WO}_{4}$ as a solvent $[1,3]$. Its structure (monoclinic, sp. gr. $\mathrm{C}^{4}{ }_{2 \mathrm{~h}}-\mathrm{P} 2 / \mathrm{c}$ ) [16] was confirmed by using X-ray powder diffraction. In $\mathrm{MgWO}_{4}$, the $\mathrm{Yb}^{3+}$ ions are replacing the $\mathrm{Mg}^{2+}$ ones in a single type of sites (Wyckoff position: $2 f$, site symmetry: $\mathrm{C}_{2}$, VI-fold oxygen coordination in distorted $\left[\mathrm{Mg} \mid \mathrm{YbO}_{6}\right]$ polyhedra), Fig. 1(b). Charge compensation is provided by $\mathrm{Na}^{+}$cations entering from the melt [3]. The corresponding ionic radii are $R_{\mathrm{Yb}}=0.868 \AA, R_{\mathrm{Mg}}=0.72 \AA$ and $R_{\mathrm{Na}}=1.02 \AA$. The concentration of $\mathrm{Yb}^{3+}$ ions in the crystal $N_{\mathrm{Yb}}$ was $1.82 \times 10^{20} \mathrm{~cm}^{-3}$ (as determined by Inductively Coupled Plasma Atomic Emission Spectroscopy). Note that the increase of $\mathrm{Yb}^{3+}$ doping level is mainly limited by the heterovalent doping mechanism; this would also lead to the deteriorated thermal properties of the crystal.

Monoclinic $\mathrm{Yb}^{3+}: \mathrm{MgWO}_{4}$ is optically biaxial (point group 2/m). At the wavelength of $\sim 1 \mu \mathrm{m}$, the principal refractive indices are $n_{\mathrm{p}}=1.97, n_{\mathrm{m}}=2.03$ and $n_{\mathrm{g}}=2.13 \pm 0.02$ according to the $n_{\mathrm{p}}<n_{\mathrm{m}}<n_{\mathrm{g}}$ convention. One of the optical indicatrix axes $\left(N_{\mathrm{m}}\right)$ coincides with the $\mathrm{C}_{2}$ symmetry axis (the $\boldsymbol{b}$-axis) and other two $\left(N_{\mathrm{p}}\right.$ and $\left.N_{\mathrm{g}}\right)$ are lying in the orthogonal mirror plane (the $\boldsymbol{a}$-c plane), Fig. 1. The angle $N_{\mathrm{p}} \wedge \boldsymbol{c}=37.1^{\circ}$, measured within the obtuse angle $\beta$.

Room-temperature (RT, $293 \mathrm{~K}$ ) absorption, $\sigma_{\text {abs, }}$ cross-sections corresponding to the ${ }^{2} \mathrm{~F}_{7 / 2} \rightarrow{ }^{2} \mathrm{~F}_{5 / 2}$ transition are shown in Fig. 2(a) for the principal light polarizations $\boldsymbol{E} \| N_{\mathrm{p}}, N_{\mathrm{m}}$ and $N_{\mathrm{g}}$. The maximum $\sigma_{\text {abs }}$ is $6.16 \times 10^{-20} \mathrm{~cm}^{2}$ at $974.0 \mathrm{~nm}$ (the zero-phonon line, ZPL, at RT) and the corresponding full width at half maximum (FWHM) of the absorption peak is $5.6 \mathrm{~nm}$ (for $\boldsymbol{E} \| N_{\mathrm{g}}$ ). The stimulated-emission (SE) cross-sections, $\sigma_{\mathrm{SE}}$, were calculated using a combination of the Füchtbauer-Ladenburg (F-L) equation [17] based on the measured luminescence spectra, and the reciprocity method (RM) [18] based on the determined Stark splitting). The maximum $\sigma_{\text {SE }}$ reaches $6.2 \times 10^{-20} \mathrm{~cm}^{2}$ at $1056.7 \mathrm{~nm}$ for $\boldsymbol{E} \| N_{\mathrm{m}} . \mathrm{Yb}^{3+}: \mathrm{MgWO}_{4}$ exhibits a strong anisotropy of the SE cross-sections at this wavelength: $\sigma_{\mathrm{SE}}(m)$ : $\sigma_{\mathrm{SE}}(g)=3.7$ and $\sigma_{\mathrm{SE}}(m): \sigma_{\mathrm{SE}}(p)=5.5$, which is a prerequisite for a linearly polarized laser emission. From the luminescence spectra (measured with $\lambda_{\mathrm{exc}}=972 \mathrm{~nm}$ ), the emission bandwidth is $18.7 \mathrm{~nm}$ $\left(\boldsymbol{E} \| N_{\mathrm{m}}\right.$ ) and $>50 \mathrm{~nm}$ (structured spectrum, $\boldsymbol{E} \| N_{\mathrm{g}}$ ). $\mathrm{Yb}^{3+}: \mathrm{MgWO}_{4}$ exhibits a single-exponential luminescence decay with a lifetime $\tau_{u m}$ of $366 \mu$ s, as measured for a powdered sample to avoid radiation trapping. The ${ }^{2} \mathrm{~F}_{5 / 2} \rightarrow{ }^{2} \mathrm{~F}_{7 / 2}$ transition of $\mathrm{Yb}^{3+}$ represents a quasithree-level laser scheme with reabsorption.
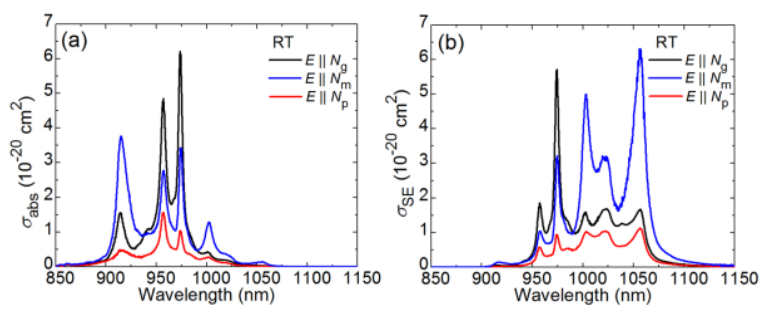

Fig. 2. RT (a) absorption, $\sigma_{\mathrm{abs}}$, and (b) stimulated-emission, $\sigma_{\mathrm{SE}}$, crosssection spectra of $\mathrm{Yb}^{3+}$ in monoclinic $\mathrm{MgWO}_{4}$ for $\boldsymbol{E} \| N_{\mathrm{p}}, N_{\mathrm{m}}$ and $N_{\mathrm{g}}$.

Thus, gain cross-sections, $\sigma_{\text {gain }}=\beta \sigma_{\mathrm{SE}}-(1-\beta) \sigma_{\mathrm{abs}}$, where $\beta=N_{2}\left({ }^{2} \mathrm{~F}_{5} / 2\right) / N_{\mathrm{Yb}}$ is the inversion ratio, and $N_{2}$ is the upper laser level population, are calculated to predict the spectral properties of laser emission, see Fig. 3 for $\boldsymbol{E} \| N_{\mathrm{m}}$ and $\boldsymbol{E} \| N_{\mathrm{g}}$. For $\boldsymbol{E} \| N_{\mathrm{m}}$, a local peak in the gain spectra is observed at $\sim 1057 \mathrm{~nm}$ and the gain bandwidth $\Delta \lambda_{\mathrm{g}}$ is $15.1 \mathrm{~nm}$ (FWHM, for $\beta=0.1$ ). For $\boldsymbol{E} \| N_{\mathrm{g}}$ a similar behavior is observed while the gain spectra are broader, $\Delta \lambda_{\mathrm{g}}=26.1 \mathrm{~nm}$.
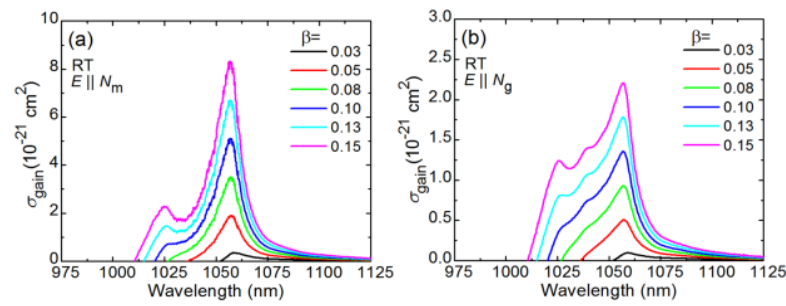

Fig. 3. RT gain cross-sections, $\sigma_{\text {gain }}=\beta \sigma_{\mathrm{SE}}-(1-\beta) \sigma_{\mathrm{abs}}$, where $\beta=N_{2}\left(2 \mathrm{~F}_{5 / 2}\right) / N_{\mathrm{Yb}}$ is the inversion ratio, for $\mathrm{Yb}^{3+}$ ions in monoclinic $\mathrm{MgWO}_{4}$ crystal. The light polarizations are (a) $\boldsymbol{E} \| N_{\mathrm{m}}$ and (b) $\boldsymbol{E} \| N_{\mathrm{g}}$.

The polarized Raman spectra of an $N_{\mathrm{m}}$-cut $\mathrm{Yb}^{3+}: \mathrm{MgWO}_{4}$ crystal are shown in Fig. 4 for the $m(i j) m$, where $i, j=p, g$, configurations (using Porto's notation). The excitation wavelength is $\lambda_{\text {exc }}=514 \mathrm{~nm}$. The most intense vibration is observed at $915.7 \mathrm{~cm}^{-1}$ (the FWHM of the Raman band is $15.0 \mathrm{~cm}^{-1}$ ) and assigned to symmetric stretching $\mathrm{W}-0$ vibrations $v_{1}\left(\mathrm{~A}_{1 \mathrm{~g}}\right)$ in the $\mathrm{WO}_{6}$ octahedra [2]. $\mathrm{Yb}^{3+}: \mathrm{MgWO}_{4}$ is promising for self-Raman frequency conversion.

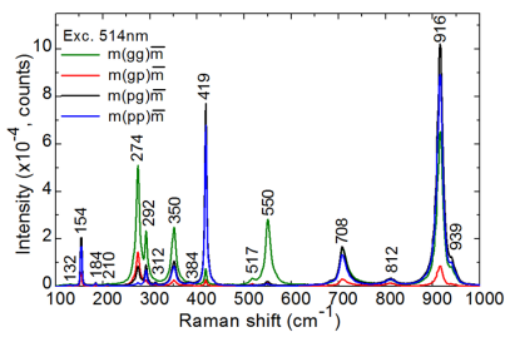

Fig. 4. Polarized Raman spectra for $\mathrm{Yb}^{3+}: \mathrm{MgWO}_{4}$ for the $m(x y) m$ configurations (Porto's notation), numbers indicate the Raman frequencies in $\mathrm{cm}^{-1}$.

To resolve the Stark splitting of $\mathrm{Yb}^{3+}$ multiplets, the absorption and luminescence spectra were measured in the temperature range of 6-300 K, Fig. 5. For $\mathrm{Yb}^{3+}$ ions in $\mathrm{C}_{2}$ symmetry sites, there is a total of $2 J+1$ Stark sub-levels for each ${ }^{2 S+1}{ }^{\mathrm{L}}$, multiplet, numbered as $0 . .3$ for ${ }^{2} \mathrm{~F}_{7 / 2}$ and $0^{\prime} . .2^{\prime}$ for ${ }^{2} \mathrm{~F}_{5 / 2}$. The interpretation of the Stark transitions was carried out accounting for the Raman spectra. 

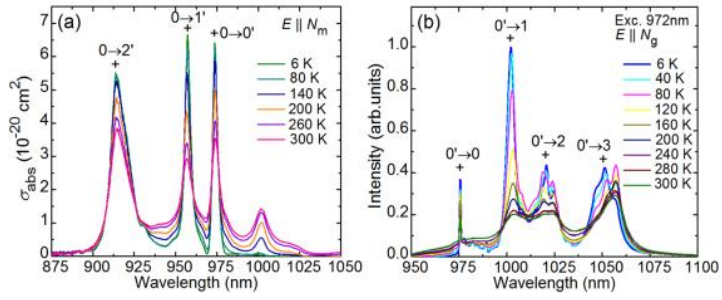

Fig. 5. Low temperature spectroscopy of $\mathrm{Yb}: \mathrm{MgWO}_{4}$ : (a) absorption spectra for $\boldsymbol{E} \| N_{\mathrm{m}}$; (b) luminescence spectra for $\boldsymbol{E} \| N_{\mathrm{g}}, \lambda_{\mathrm{exc}}=972 \mathrm{~nm}$. The "+" marks indicate Stark transitions.

The energy-level scheme of $\mathrm{Yb}^{3+}$ ions in $\mathrm{MgWO}_{4}$ is shown in Fig. 6(a). The ZPL (the transition between the lowest sub-levels of both multiplets) has an energy $E_{\mathrm{ZPL}}=10275 \mathrm{~cm}^{-1}$. The partition functions for the lower and upper multiplets are $Z_{1}=1.352$ and $Z_{2}=$ 1.469 , respectively $\left(Z_{1} / Z_{2}=0.920\right)$. The total Stark splitting of the ground-state, $\Delta \mathrm{E}\left({ }^{2} \mathrm{~F}_{7 / 2}\right)=765 \mathrm{~cm}^{-1}$, exceeds that in other known tungstate crystals [8,19], Fig. 6(b). For the $\mathrm{RE}^{3+}$ ions, the barycenter of any ${ }^{2 \mathrm{~S}+1} \mathrm{LJ}_{j} 4 \mathrm{f}^{n}$ multiplet shows a linear variation vs. the barycenter of any other isolated multiplet, which is expressed as a barycenter plot [20], see Fig. 6(c). The barycenter energies $\left\langle E\left({ }^{2} \mathrm{~F}_{5 / 2}\right)\right\rangle$ and $<E\left({ }^{2} \mathrm{~F}_{7 / 2}\right)>$ for $\mathrm{Yb}^{3+}: \mathrm{MgWO}_{4}$ agree well with this plot.

In Table 1, we compare the emission properties of $\mathrm{Yb}^{3+}: \mathrm{MgWO}_{4}$ with other well-known tungstate laser crystals, namely, monoclinic

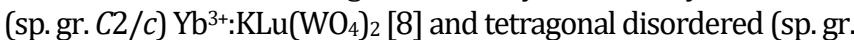
$\left.I 4_{1} / a\right) \mathrm{Yb}^{3+}: \mathrm{NaY}\left(\mathrm{WO}_{4}\right)_{2}$ [21]. $\mathrm{Yb}^{3+}: \mathrm{MgWO}_{4}$ has higher SE crosssections, while its gain bandwidths are comparable to those of monoclinic double tungstates.

Table 1. Spectroscopic Properties* of $\mathrm{Yb}^{3+}$ in Tungstate Crystals

\begin{tabular}{|c|c|c|c|c|c|c|}
\hline Crystal & Site & $\begin{array}{l}\lambda_{\mathrm{em}}, \\
\mathrm{nm}\end{array}$ & $\begin{array}{l}\Delta \lambda_{\mathrm{g}}, \\
\mathrm{nm}\end{array}$ & $\begin{array}{l}\sigma_{\mathrm{SE}}, \\
10^{-20} \mathrm{~cm}^{2}\end{array}$ & $\begin{array}{l}\tau_{\text {lum }}, \\
\mu \mathrm{s}\end{array}$ & Ref. \\
\hline \multirow[t]{2}{*}{$\mathrm{NaY}\left(\mathrm{WO}_{4}\right)_{2}$} & $\mathrm{~S}_{4}$ & $1018(\pi)$ & $33.9(\pi)$ & $1.38(\pi)$ & 309 & [21] \\
\hline & & $1024(\sigma)$ & $25.9(\sigma)$ & $0.86(\sigma)$ & & \\
\hline \multirow[t]{2}{*}{$\mathrm{KLu}\left(\mathrm{WO}_{4}\right)_{2}$} & $\mathrm{C}_{2}$ & $1026.7(\mathrm{~m})$ & $20.2(\mathrm{~m})$ & $2.6(\mathrm{~m})$ & 275 & [8] \\
\hline & & $1041.2(p)$ & $28.0(p)$ & $1.3(p)$ & & \\
\hline \multirow[t]{2}{*}{$\mathrm{MgWO}_{4}$} & $\mathrm{C}_{2}$ & $1056.7(\mathrm{~m})$ & $15.1(\mathrm{~m})$ & $6.25(\mathrm{~m})$ & 366 & $*$ \\
\hline & & $1056.6(\mathrm{~g})$ & $26.1(\mathrm{~g})$ & $1.68(\mathrm{~g})$ & & \\
\hline
\end{tabular}

$* \lambda_{\text {em }}$ - emission wavelength, $\Delta \lambda_{\mathrm{g}}-$ gain bandwidth $(\beta=0.1), \sigma_{\mathrm{SE}}-\mathrm{SE}$ cross-section, $\tau_{\text {lum }}$ - reabsorption-free luminescence lifetime.

For laser experiments, a rectangular sample was cut from the 1.25 at.\% $\mathrm{Yb}^{3+}: \mathrm{MgWO}_{4}$ crystal for light propagation along the $N_{\mathrm{p}}$ optical indicatrix axis ( $N_{\mathrm{p}}$-cut). It had a thickness of $3.1 \mathrm{~mm}$ and an aperture of $4 \times 4 \mathrm{~mm}^{2}$. This crystal orientation was selected because it gives access to the high-gain light polarization $\left(\boldsymbol{E} \| N_{\mathrm{m}}\right)$. The uncoated crystal was mounted in a Cu-holder using Indium foil for better thermal thermal contact from all lateral sides. The holder was cooled to $\sim 14^{\circ} \mathrm{C}$ by circulating water. The crystal was inserted in a compact plano-plano (microchip-type) laser cavity, Fig. 7, formed by a flat pump mirror (PM) coated for high transmission (HT) at 0.88-0.99 $\mu \mathrm{m}$ and for high reflection (HR) at 1.02-1.23 $\mu \mathrm{m}$, and a set of flat output couplers (OCs) with a transmission $T_{\text {OC }}$ of $0.5 \% . . .10 \%$ at the laser wavelength. Both the PM and the OC were placed close to the crystal with minimum air gaps, so that the geometrical cavity length was $\sim 3.1 \mathrm{~mm}$. The microchip laser concept benefits from a robust and compact design and good cavity stability.

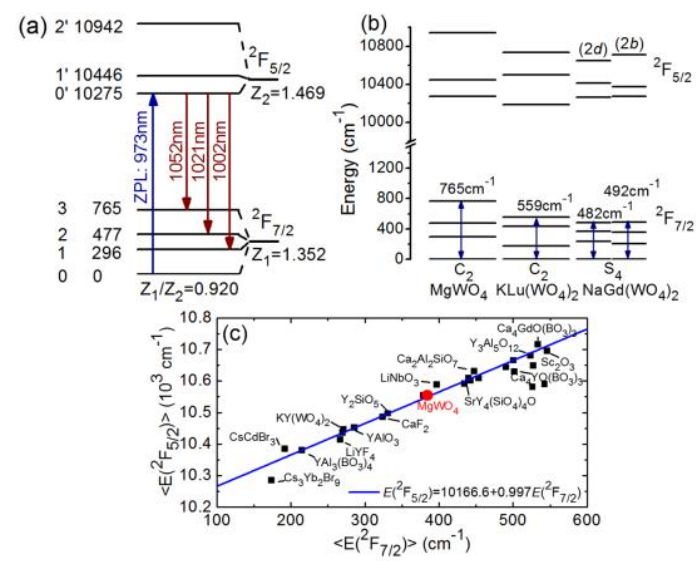

Fig. 6. Stark splitting of $\mathrm{Yb}^{3+}$ multiplets in $\mathrm{MgWO}_{4}$ : (a) Energy-level scheme, numbers indicate the energy in $\mathrm{cm}^{-1}, \mathrm{Z}_{1(2)}$ are the partition functions; (b) Stark splitting of $\mathrm{Yb}^{3+}$ in tungstate crystals: $\mathrm{MgWO}_{4}$, $\mathrm{KLu}\left(\mathrm{WO}_{4}\right)_{2}$ [8], $\mathrm{NaGd}\left(\mathrm{WO}_{4}\right)_{2}$ [19] $\left(\mathrm{C}_{2}\right.$ and $\mathrm{S}_{4}-\mathrm{Yb}^{3+}$ site symmetries); (c) barycenter plot [20] for $\mathrm{Yb}^{3+}$ ions showing the result for $\mathrm{MgWO}_{4}$.

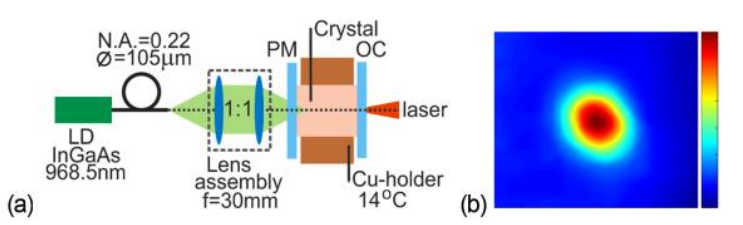

Fig. 7. (a) Scheme of the compact diode-pumped $\mathrm{Yb}^{3+}: \mathrm{MgWO}_{4}$ laser: $\mathrm{LD}$ - laser diode, PM - pump mirror, OC - output coupler; (b) typical profile of the laser beam in the far-field (the beam ellipticity originates from the astigmatic thermal lens), $P_{\mathrm{abs}} \approx 10 \mathrm{~W}$.

The $N_{\mathrm{p}}$-cut $\mathrm{Yb}^{3+}: \mathrm{MgWO}_{4}$ crystal generated a maximum output power of 18.2 W at $\sim 1056 \mathrm{~nm}$ with a slope efficiency $\eta$ of $~ 89 \%$ ( $v S$. the absorbed pump power $P_{\mathrm{abs}}$ ), Fig. 8(a). The laser threshold was at $P_{\text {abs }}=0.54 \mathrm{~W}$ and the optical-to-optical efficiency $\eta_{\text {opt }}$ amounted to $33.7 \%$ ( $v$ s. the pump power incident on the crystal). All these values are specified for $T_{\mathrm{OC}}=10 \%$. The laser output was linearly polarized $\left(\boldsymbol{E} \| N_{\mathrm{m}}\right)$ and the polarization was intrinsically selected by the gain anisotropy, Fig. 2(b). For all studied OCs, the emission wavelength was $\sim 1.06 \mu \mathrm{m}$, Fig. 3(a), in agreement with the gain spectra. A slight blue-shift of the laser wavelength with increasing output coupling was detected, Fig. 8(b), and ascribed to the quasi-three-level nature of the $\mathrm{Yb}^{3+}$ laser scheme exhibiting reabsorption at the laser wavelength. The laser operation in the plano-plano cavity was supported by a positive (focusing) thermal lens. For $T_{\mathrm{OC}}<10 \%$, power scaling was limited by a thermal roll-over probably because of too high intracavity laser intensity. The determined laser slope efficiency gives an estimation of the roundtrip passive loss $L$ of $0.35 \%$ (loss coefficient: $\delta_{\text {loss }}=0.0056 \mathrm{~cm}^{-1}$ ). No crystal fracture was observed up to at least $P_{\mathrm{abs}}=22.5 \mathrm{~W}$ (limited by the available pump).

In Table 2, we compare the output characteristics of compact diode-pumped lasers based on $\mathrm{Yb}^{3+}$-doped oxide crystals and reported recently. The superior laser results achieved with $\mathrm{Yb}^{3+}: \mathrm{MgWO}_{4}$ compared to previous studies with other tungstate crystals, $\mathrm{Yb}^{3+}: \mathrm{NaY}\left(\mathrm{WO}_{4}\right)_{2}$ and $\mathrm{Yb}^{3+}: \mathrm{KLu}\left(\mathrm{WO}_{4}\right)_{2}$, are attributed to its better thermo-mechanical properties. crystals, $\mathrm{Yb}^{3+}: \mathrm{NaY}\left(\mathrm{WO}_{4}\right)_{2}$ and $\mathrm{Yb}^{3+}: \mathrm{KLu}\left(\mathrm{WO}_{4}\right)_{2}$, are attributed to its better thermo-mechanical properties. 


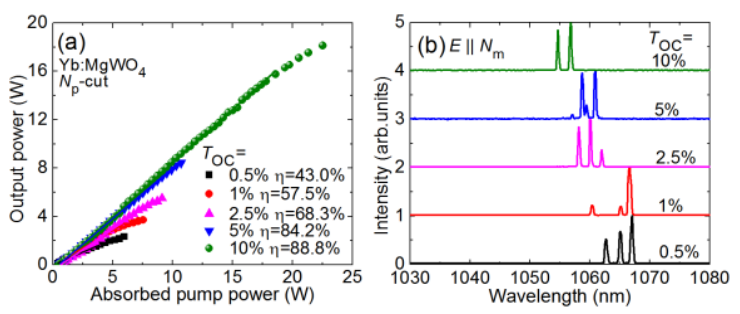

Fig. 8. Diode-pumped compact $\mathrm{Yb}^{3+}: \mathrm{MgWO}_{4}$ laser: (a) input-output dependences, $\eta$-slope efficiency; (b) typical laser emission spectra. The crystal orientation is $N_{\mathrm{p}}$-cut, the laser polarization is $\boldsymbol{E} \| N_{\mathrm{m}}$.

Table 2. Output Characteristics* of Compact Diode-Pumped Ytterbium Lasers Based on Oxide Crystals Reported So Far

\begin{tabular}{|c|c|c|c|c|c|c|}
\hline Crystal & $\begin{array}{l}\mathrm{Yb}, \\
\text { at. } \%\end{array}$ & $\begin{array}{l}P_{\text {out }}, \\
\mathrm{W}\end{array}$ & $\begin{array}{l}\lambda_{\mathrm{L}}, \\
\mathrm{nm}\end{array}$ & $\begin{array}{l}P_{\text {th }}, \\
\text { W }\end{array}$ & $\begin{array}{l}\eta \\
\%\end{array}$ & Ref. \\
\hline $\mathrm{Yb}: \mathrm{LuVO}_{4}$ & 1.5 & 8.3 & 1031 & 2.6 & 80 & [22] \\
\hline $\mathrm{Yb}: \mathrm{CaGdAlO}_{4}$ & 8 & 7.79 & $\sim 1061$ & 2.0 & 84 & [13] \\
\hline $\mathrm{Yb}: \mathrm{LuAlO}_{3}$ & 2 & 9.6 & 1041 & $\sim 1.5$ & 74 & [23] \\
\hline $\mathrm{Yb}: \mathrm{NaY}\left(\mathrm{WO}_{4}\right)_{2}$ & 4.8 & 5.2 & 1045 & 1.20 & 50 & [24] \\
\hline $\mathrm{Yb}: \mathrm{KLu}\left(\mathrm{WO}_{4}\right)_{2}$ & 5.2 & 11.0 & $\sim 1045$ & 0.61 & 80 & [25] \\
\hline $\mathrm{Yb}: \mathrm{MgWO}_{4}$ & 1.25 & 18.2 & $\sim 1056$ & 0.54 & 89 & $* *$ \\
\hline $\mathrm{Yb}: \mathrm{Ca}_{4} \mathrm{GdO}\left(\mathrm{BO}_{3}\right)_{3}$ & 10 & 18.2 & 1032 & $\sim 1$ & 70 & [26] \\
\hline $\mathrm{Yb}: \mathrm{YAl}_{3}\left(\mathrm{BO}_{3}\right)_{4}$ & 5.6 & 10.6 & 1042 & 0.79 & 72 & [27] \\
\hline $\mathrm{Yb}: \mathrm{Lu}_{3} \mathrm{Ga}_{5} \mathrm{O}_{12}$ & 7.1 & 8.97 & 1040 & 1.22 & 75 & [28] \\
\hline
\end{tabular}

${ }^{*} P_{\text {out }}$ - output power, $\lambda_{\mathrm{L}}$ - laser wavelength; $P_{\text {th }}-$ threshold pump power, $\eta$-slope efficiency ( $v s$. absorbed pump power); ${ }^{* *}$ This work.

To conclude, monoclinic $\mathrm{Yb}^{3+}: \mathrm{MgWO}_{4}$ is a promising crystal for compact, highly-efficient and high-power lasers at 1 $\mu \mathrm{m}$ thanks to a combination of attractive thermal and spectroscopic properties. We report on the first laser operation of $\mathrm{Yb}^{3+}: \mathrm{MgWO}_{4}$ in a microchip-type laser cavity yielding $>18 \mathrm{~W}$ of linearly polarized output at $\sim 1.06 \mu \mathrm{m}$ with a slope efficiency (88.8\%) almost approaching the Stokes limit, $\eta_{\mathrm{St}}=\lambda_{\mathrm{P}} / \lambda_{\mathrm{L}}=91.7 \%$. This is attributed to weaknon-radiative relaxation, low optical losses and good modematching provided by the positive thermal lens for the selected crystal orientation and the results achieved in this work represent a record for $\mathrm{Yb}^{3+}$-doped tungstate laser crystals.

Funding. National Natural Science Foundation of China (61975208, 51761135115, 61850410533, 61575199, 61875199); Deutsche Forschungsgemeinschaft (PE 607/14-1); LaserlabEurope (654148); Natural Science Foundation of Jiangsu Province (SBK2019030177); Sino-German Scientist Cooperation and Exchanges Mobility Programme (M-0040); Spanish Government, MINECO (MAT2016-75716-C2-1-R (AEI/FEDER,UE); Generalitat de Catalunya (2017SGR755).

Acknowledgment. Yongguang Zhao acknowledges financial support from the Alexander von Humboldt Foundation through a Humboldt fellowship.

Disclosures. The authors declare no conflicts of interest. References
1. L. Zhang, W. Chen, J. Lu, H. Lin, L. Li, G. Wang, G. Zhang, and Z. Lin, Opt. Mater. Express 6, 1627 (2016).

2. L. Zhang, H. Lin, G. Zhang, X. Mateos, J. M. Serres, M. Aguiló, F. Díaz, U. Griebner, V. Petrov, Y. Wang, P. Loiko, E. Vilejshikova, K. Yumashev, Z. Lin, and W. Chen, Opt. Express 25, 3682 (2017).

3. L. Zhang, P. Loiko, J.M. Serres, E. Kifle, H. Lin, G. Zhang, E. Vilejshikova, E. Dunina, A. Kornienko, L. Fomicheva, U. Griebner, V. Petrov, Z. Lin, W. Chen, K. Subbotin, M. Aguiló, F. Díaz, and X. Mateos, J. Lumin. 213, 316 (2019).

4. E. Cavalli, A. Belletti, and M. G. Brik, J. Phys. Chem. Solids 69, 29 (2008).

5. V. B. Mikhailik, H. Kraus, V. Kapustyanyk, M. Panasyuk, P. Yu, V. Tsybulskyi, and L. Vasylechko, J. Phys.: Cond. Matter 20, 365219 (2008).

6. L. Li, Y. Yu, G. Wang, L. Zhang, and Z. Lin, Cryst. Eng. Comm. 15, 6083 (2013).

7. L. Zhang, Y. Huang, S. Sun, F. Yuan, Z. Lin, and G. Wang, J. Lumin. 169, 161 (2016).

8. V. Petrov, M. C. Pujol, X. Mateos, Ò. Silvestre, S. Rivier, M. Aguiló, R. M. Solé, J. H. Liu, U. Griebner, and F. Díaz, Laser Photon. Rev. 1, 179 (2007).

9. P. A. Loiko, K. V. Yumashev, N. V. Kuleshov, G. E. Rachkovskaya, and A. A. Pavlyuk, Opt. Mater. 34, 23 (2011).

10. P. Loiko, L. Zhang, J. M. Serres, Y. Wang, M. Aguiló, F. Díaz, Z. Lin, H. Lin, G. Zhang, E. Vilejshikova, E. Dunina, A. Kornienko, L. Fomicheva, V. Petrov, U. Griebner, W. Chen, and X. Mateos, J. Alloys Compd. 763, 581 (2018).

11. P. Loiko, J. M. Serres, X. Mateos, M. Aguiló, F. Díaz, L. Zhang, Z. Lin, H. Lin, G. Zhang, K. Yumashev, V. Petrov, U. Griebner, Y. Wang, S. Y. Choi, F. Rotermund, and W. Chen, Opt. Lett. 42, 1177 (2017).

12. Y. Wang, W. Chen, M. Mero, L. Zhang, H. Lin, Z. Lin, G. Zhang, F. Rotermund, Y. J. Cho, P. Loiko, X. Mateos, U. Griebner, and V. Petrov, Opt. Lett. 42, 3076 (2017).

13. P. Loiko, J. M. Serres, X. Mateos, X. Xu, J. Xu, V. Jambunathan, A. Lucianetti, T. Mocek, X. Zhang, U. Griebner, V. Petrov, M. Aguiló, F. Díaz, and A. Major, Opt. Lett. 42, 2431 (2017).

14. J. Lu, H. Lin, G. Zhang, B. Li, L. Zhang, Z. Lin, Y.-F. Chen, V. Petrov, and W. Chen, Laser Phys. Lett. 14, 085807 (2017)

15. H. Lin, G. Zhang, L. Zhang, Z. Lin, F. Pirzio, A. Agnesi, V. Petrov, and W. Chen, Opt. Express 25, 11827 (2017).

16. V. B. Kravchenko, J. Struct. Chem. 10, 139 (1969).

17. B. Aull and H. Jenssen, IEEE J. Quantum Electron. 18, 925 (1982).

18. S. A. Payne, L. L. Chase, L. K. Smith, W. L. Kway, and W. F. Krupke, IEEE J. Quantum Electron. 28, 2619 (1992).

19. C. Cascales, M. D. Serrano, F. Esteban-Betegón, C. Zaldo, R. Peters, K. Petermann, G. Huber, L. Ackermann, D. Rytz, C. Dupré, M. Rico J. Liu, U. Griebner, and V. Petrov, Phys. Rev. B 74, 174114 (2006).

20. P. H. Haumesser, R. Gaumé, B. Viana, E. Antic-Fidancev, and D. Vivien, J. Phys.: Cond. Matter 13, 5427 (2001).

21. A. Garcia-Cortes, J. M. Cano-Torres, M. D. Serrano, C. Cascales, C. Zaldo, S. Rivier, X. Mateos, U. Griebner, and V. Petrov, IEEE J. Quantum Electron. 43, 758 (2007).

22. J. Liu, V. Petrov, H. Zhang, J. Wang, and M. Jiang, Opt. Lett. 31, 3294 (2006).

23. A. Rudenkov, V. Kisel, A. Yasukevich, K. Hovhannesyan, A. Petrosyan, and N. Kuleshov, Opt. Lett. 42, 2415 (2017).

24. J. Liu, H. Zhang, J. Wang, and V. Petrov, Opt. Express 15, 12900 (2007).

25. J. Liu, V. Petrov, X. Mateos, H. Zhang, and J. Wang, Opt. Lett. 32, 2016 (2007).

26. X. Chen, L. Wang, J. Liu, Y. Guo, W. Han, H. Xu, H. Yu, and H. Zhang, Opt. Laser Tehcnol. 79, 74 (2016).

27. J. Liu, X. Mateos, H. Zhang, J. Li, J. Wang, and V. Petrov, IEEE J. Quantum Electron. 43, 385 (2007).

28. J. M. Serres, V. Jambunathan, P. Loiko, X. Mateos, H. Yu, H. Zhang, J. Liu, A. Lucianetti, T. Mocek, K. Yumashev, U. Griebner, V. Petrov, M. Aguiló, and F. Díaz, Opt. Mater. Express 6, 46 (2016). 


\section{References}

1. L. Zhang, W. Chen, J. Lu, H. Lin, L. Li, G. Wang, G. Zhang, and Z. Lin, "Characterization of growth, optical properties, and laser performance of monoclinic Yb:MgWO ${ }_{4}$ crystal," Opt. Mater. Express 6(5), 1627-1634 (2016).

2. L. Zhang, H. Lin, G. Zhang, X. Mateos, J. M. Serres, M. Aguiló, F. Díaz, U. Griebner, V. Petrov, Y. Wang, P. Loiko, E. Vilejshikova, K. Yumashev, Z. Lin, and W. Chen, "Crystal growth, optical spectroscopy and laser action of $\mathrm{Tm}^{3+}$-doped monoclinic magnesium tungstate," Opt. Express 25(4), 36823693 (2017).

3. L. Zhang, P. Loiko, J.M. Serres, E. Kifle, H. Lin, G. Zhang, E. Vilejshikova, E. Dunina, A. Kornienko, L. Fomicheva, U. Griebner, V. Petrov, Z. Lin, W. Chen, K. Subbotin, M. Aguiló, F. Díaz, and X. Mateos, "Growth, spectroscopy and first laser operation of monoclinic $\mathrm{Ho}^{3+}: \mathrm{MgWO}_{4} \mathrm{crystal}^{\prime}$ J. Lumin. 213, 316-325 (2019).

4. E. Cavalli, A. Belletti, and M. G. Brik, "Optical spectra and energy levels of the $\mathrm{Cr}^{3+}$ ions in $\mathrm{MWO}_{4}(\mathrm{M}=\mathrm{Mg}, \mathrm{Zn}, \mathrm{Cd})$ and $\mathrm{MgMoO}_{4}$ crystals," J. Phys. Chem. Solids 69(1), 29-34 (2008).

5. V. B. Mikhailik, H. Kraus, V. Kapustyanyk, M. Panasyuk, P. Yu, V. Tsybulskyi, and L. Vasylechko, "Structure, luminescence and scintillation properties of the $\mathrm{MgWO}_{4}-\mathrm{MgMoO}_{4}$ system," J. Phys.: Cond. Matter 20(36), 365219-18 (2008).

6. L. Li, Y. Yu, G. Wang, L. Zhang, and Z. Lin, "Crystal growth, spectral properties and crystal field analysis of $\mathrm{Cr}^{3+}: \mathrm{MgWO}_{4}$, " Cryst. Eng. Comm. 15(30), 6083-6089 (2013).

7. L. Zhang, Y. Huang, S. Sun, F. Yuan, Z. Lin, and G. Wang, "Thermal and spectral characterization of $\mathrm{Cr}^{3+}: \mathrm{MgWO}_{4}$ - a promising tunable laser material," J. Lumin. 169, Part A, 161-164 (2016).

8. V. Petrov, M. C. Pujol, X. Mateos, Ò. Silvestre, S. Rivier, M. Aguiló, R. M. Solé, J. H. Liu, U. Griebner, and F. Díaz, "Growth and properties of $\mathrm{KLu}\left(\mathrm{WO}_{4}\right)_{2}$, and novel ytterbium and thulium lasers based on this monoclinic crystalline host," Laser Photon. Rev. 1(2), 179-212 (2007).

9. P.A. Loiko, K.V. Yumashev, N.V. Kuleshov, G.E. Rachkovskaya, and A.A. Pavlyuk, "Detailed characterization of thermal expansion tensor in monoclinic $\mathrm{KRe}\left(\mathrm{WO}_{4}\right)_{2}$ (where $\mathrm{Re}=\mathrm{Gd}, \mathrm{Y}, \mathrm{Lu}, \mathrm{Yb}$ )," Opt. Mater. 34(1), 2326 (2011).

10. P. Loiko, L. Zhang, J.M. Serres, Y. Wang, M. Aguiló, F. Díaz, Z. Lin, H. Lin, G. Zhang, E. Vilejshikova, E. Dunina, A. Kornienko, L. Fomicheva, V. Petrov, U. Griebner, W. Chen, and X. Mateos, "Monoclinic Tm:MgWO ${ }_{4}$ crystal: Crystal-field analysis, tunable and vibronic laser demonstration," J. Alloys Compd. 763, 581-591 (2018).

11. P. Loiko, J. M. Serres, X. Mateos, M. Aguiló, F. Díaz, L. Zhang, Z. Lin, H. Lin, G. Zhang, K. Yumashev, V. Petrov, U. Griebner, Y. Wang, S. Y. Choi, F. Rotermund, and W. Chen, "Monoclinic $\mathrm{Tm}^{3+}: \mathrm{MgWO}_{4}$ : a promising crystal for continuous-wave and passively Q-switched lasers at $\sim 2 \mu \mathrm{m}$," Opt. Lett. 42(6), 1177-1180 (2017).

12. Y. Wang, W. Chen, M. Mero, L. Zhang, H. Lin, Z. Lin, G. Zhang, F. Rotermund, Y. J. Cho, P. Loiko, X. Mateos, U. Griebner, and V. Petrov, "Sub-100 fs Tm:MgWO 4 laser at $2017 \mathrm{~nm}$ mode locked by a graphene saturable absorber," Opt. Lett. 42(16), 3076-3079 (2017).

13. P. Loiko, J. M. Serres, X. Mateos, X. Xu, J. Xu, V. Jambunathan, A. Lucianetti, T. Mocek, X. Zhang, U. Griebner, V. Petrov, M. Aguiló, F. Díaz, and A. Major, "Microchip Yb:CaLnAlO 4 lasers up to 91\% slope efficiency," Opt. Lett. 42(13), 2431-2434 (2017).

14. J. Lu, H. Lin, G. Zhang, B. Li, L. Zhang, Z. Lin, Y.-F. Chen, V. Petrov, and W. Chen, "Direct generation of an optical vortex beam from a diode-pumped Yb:MgWO 4 laser," Laser Phys. Lett. 14(8), 085807-1-6 (2017)

15. H. Lin, G. Zhang, L. Zhang, Z. Lin, F. Pirzio, A. Agnesi, V. Petrov, and W. Chen, "Continuous-wave and SESAM mode-locked femtosecond operation of a Yb:MgWO 4 laser," Opt. Express 25(10), 11827-11832 (2017).
16. V. B. Kravchenko, "Crystal structure of the monoclinic form of magnesium tungstate $\mathrm{MgWO}_{4}$," J. Struct. Chem. 10(1), 139-140 (1969).

17. B. Aull and H. Jenssen, "Vibronic interactions in Nd:YAG resulting in nonreciprocity of absorption and stimulated emission cross sections," IEEE J. Quantum Electron. 18(5), 925-930 (1982).

18. S. A. Payne, L. L. Chase, L. K. Smith, W. L. Kway, and W. F. Krupke, "Infrared cross-section measurements for crystals doped with $\mathrm{Er}^{3+}, \mathrm{Tm}^{3+}$, and $\mathrm{Ho}^{3+,}$, IEEE J. Quantum Electron. 28(11), 2619-2630 (1992).

19. C. Cascales, M. D. Serrano, F. Esteban-Betegón, C. Zaldo, R. Peters, K. Petermann, G. Huber, L. Ackermann, D. Rytz, C. Dupré, and M. Rico, "Structural, spectroscopic, and tunable laser properties of $\mathrm{Yb}^{3+}$-doped $\mathrm{NaGd}\left(\mathrm{WO}_{4}\right)_{2}$," Phys. Rev. B 74(17), 174114-1-15 (2006).

20. P. H. Haumesser, R. Gaumé, B. Viana, E. Antic-Fidancev, and D. Vivien, "Spectroscopic and crystal-field analysis of new Yb-doped laser materials," J. Phys.: Cond. Matter 13(23), 5427 (2001).

21. A. Garcia-Cortes, J. M. Cano-Torres, M. D. Serrano, C. Cascales, C. Zaldo, S. Rivier, X. Mateos, U. Griebner, and V. Petrov, "Spectroscopy and lasing of $\mathrm{Yb}$-doped $\mathrm{NaY}\left(\mathrm{WO}_{4}\right)_{2}$ : tunable and femtosecond mode-locked laser operation," IEEE J. Quantum Electron. 43(9), 758-764 (2007).

22. J. Liu, V. Petrov, H. Zhang, J. Wang, and M. Jiang, "High-power laser performance of $a$-cut and c-cut Yb:LuVO ${ }_{4}$ crystals," Opt. Lett. 31(22), 3294-3296 (2006).

23. A. Rudenkov, V. Kisel, A. Yasukevich, K. Hovhannesyan, A. Petrosyan, and N. Kuleshov, "Yb ${ }^{3+}: \mathrm{LuAlO}_{3}$ crystal as a gain medium for efficient broadband chirped pulse regenerative amplification," Opt. Lett. 42(13), 2415-2418 (2017).

24. J. Liu, H. Zhang, J. Wang, and V. Petrov, "Continuous-wave and Qswitched laser operation of $\mathrm{Yb}: \mathrm{NaY}\left(\mathrm{WO}_{4}\right)_{2}$ crystal," Opt. Express 15(20), 12900-12904 (2007).

25. J. Liu, V. Petrov, X. Mateos, H. Zhang, and J. Wang, "Efficient high-power laser operation of $\mathrm{Yb}: \mathrm{KLu}\left(\mathrm{WO}_{4}\right)_{2}$ crystals cut along the principal optical axes," Opt. Lett. 32(14), 2016-2018 (2007).

26. X. Chen, L. Wang, J. Liu, Y. Guo, W. Han, H. Xu, H. Yu, and H. Zhang, "Highpower $\mathrm{CW}$ and passively Q-switched laser operation of $\mathrm{Yb}: \mathrm{GdCa}_{4} \mathrm{O}\left(\mathrm{BO}_{3}\right)_{3}$ crystal," Opt. Laser Tehcnol. 79, 74-78 (2016).

27. ] J. Liu, X. Mateos, H. Zhang, J. Li, J. Wang, and V. Petrov, "High-power laser performance of $\mathrm{Yb}: \mathrm{YAl}_{3}\left(\mathrm{BO}_{3}\right)_{4}$ crystals cut along the crystallographic axes," IEEE J. Quantum Electron. 43(5), 385-390 (2007).

28. J. M. Serres, V. Jambunathan, P. Loiko, X. Mateos, H. Yu, H. Zhang, J. Liu, A. Lucianetti, T. Mocek, K. Yumashev, U. Griebner, V. Petrov, M. Aguiló, and F. Díaz, "Microchip laser operation of Yb-doped gallium garnets," Opt. Mater. Express 6(1), 46-57 (2016). 